\title{
LATAR BELAKANG DAN MASA DEPAN LIBYA PASCA ARAB SPRING
}

\author{
DANU EKO AGUSTINOVA \\ Jurusan Pendidikan Sejarah FIS UNY \\ e-mail: revolusioner1989@gmail.com
}

\begin{abstract}
Abstrak
Penelitian bertujuan untuk: 1) mendeskripsikan faktor-faktor penyebab terjadinya Arab Spring di Libya yang berakibat pada pergantian pemerintahan di Libya serta 2) menganalisis masa depan Libya setelah terjadinya Arab Spring. Menggunakan metode sejarah melalui empat langkah metode yaitu heuristic, kritik sumber, interpretasi dan penulisan/historiografi dengan endekatan sosiologis, budaya, psikologis, dan politik. Hasil penelitian menunjukkan selama 42 tahun masa pemerintahan Moammar Qaddafi Libya mengalami krisis kebebasan, demokrasi dan tingginya pengangguran dan kemiskinan. Hal ini dikarenakan pemaksaan pemikiran pribadinya tentang "Teori Dunia Ketiga" serta dominasi Qaddafi yang absolut di Libya. Keberhasilan Arab Spring di Libya, menjadikan pemerintahan yang baru telah menyusun sistem ketatanegaraan yang baru yang mengadopsi segala aspirasi dan kepentingan rakyatnya. Bidang ekonomi, Libya diprediksi akan mengadopsi sistem ekonomi liberal. Kebijakan luar negeri Libya cenderung ke arah lebih moderat.
\end{abstract}

Kata Kunci: Libya, Arab Spring.

\begin{abstract}
This research aims to: 1) describe the factors that cause the Arab Spring in Libya which resulted in the change of the government in Libya and 2) analyze the future of Libya after the Arab Spring. This research utilizes historical methods which include heuristic, source criticism, interpretation and writing / historiography. The approach used in this research consists of a sociological, cultural, psychological, and political. The findings show that Libya has experienced a crisis of freedom, democracy and the high unemployment and poverty for 42 years of Moammar Qaddafi the reign. This is due to the imposition of personal thoughts on the "Theory of the Third World" as well as the absolute domination of Qaddafi in Libya. The success of the Arab Spring in Libya caused the new government to develop a new state system by gathering all the aspirations and interests of its people. In the field of Economy, Libya is expected to adopt a liberal economic system. Libya's foreign policy tends to be more moderate.
\end{abstract}

Keywords: Libya, Arab Spring. 


\section{PENDAHULUAN}

Gelombang revolusi Arab Spring dimulai ketika seorang pedagang buah yang bernama Mohamed Bouazizi melakukan pembakaran diri sebagai bentuk protes terhadap pemerintah di Tunisia pada bulan Desember 2010, yang menjadi awal gelombang protes di berbagai negara Arab (Apriadi Tamburaka, 2011: 26). Sebagian protes tersebut telah dapat menumbangkan pemimpin yang lama berkuasa di negaranya. Gelombang protes yang dikenal dengan nama Arab Spring merupakan suatu ekspresi musim semi bagi demokratisasi di dunia Arab. Gelombang protes yang diawali dari Tunisia ini kemudian menjalar ke Mesir, Libya, Yaman, Bahrain, dan yang saat ini tengah bergejolak adalah Suriah.

Negara pertama, Tunisia, sebenarnya menganut sistem multi partai. Sejak merdeka dari Perancis tahun 1956 dan menyatakan sebagai Republik Tunisia tanggal 25 Juli 1957, maka partai politik yang berkuasa adalah Constitutional Democratic Rally (RCD) (Apriadi Tamburaka, 2011: 42). Presiden Tunisia yang pertama adalah Habib Bourguiba yang berkuasa dari tahun 1957 hingga 1987, yang kemudian digantikan oleh Zine el Abidine ben Ali sejak tahun 1987 hingga digulingkan tahun 2011 lalu (Apriadi Tamburaka, 2011: 19). Sebenarnya di Tunisia sudah ada demokrasi formal untuk pemilihan Presiden dan anggota Parlemen, namun demikian, pemenangnya selalu partai politik yang sama.

Sementara itu, negara kedua yaitu Mesir juga menganut sistem multi partai. Sejak revolusi tahun 1952 yang menumbangkan kekuasaan Raja Farouk, maka penguasa Mesir adalah kalangan militer. Presiden Hosni Mubarak sendiri berkuasa cukup lama dari tahun 1981 hingga digulingkan tahun 2011 lalu yang menggantikan Presiden Anwar Sadat yang tewas tertembak pada tahun 1981 (Apriadi Tamburaka, 2011: 26). Di Mesir juga sudah ada demokrasi formal, untuk memilih Presiden dan anggota Parlemen, namun demikian pemenangnya selalu partai politik yang sama. Pada tahun 2005 pernah dilakukan reformasi politik yang memungkinkan pada saat pemilu presiden yang menghadir- kan kandidat lebih dari satu.

Negara ketiga yaitu Libya. Libya merupakan sebuah negara di Afrika yang menjadi salah satu negara penghasil minyak terbesar di dunia. Sejak revolusi tahun 1969 yang menggulingkan Raja Idris, Libya dipimpin oleh tokoh muda bernama Moammar Qaddafi yang telah memerintah lebih dari 40 tahun. Revolusi itu pun ditandai dengan pengangkatan Moammar Qaddafi sebagai Brother Leader dan mengganti sistem pemerintahan. Kolonel Moammar Qaddafi, membangun Libya dengan caranya sendiri, dengan menerbitkan Kitab al-Akhdar (Buku Hijau) yang berisi tentang buku suci politik Libya (Agung D.H., 2011: 17).

Sebagai negara penghasil minyak terbesar, Libya mendapat pendapat 52,8\% hanya dari penghasilan minyak. Tetapi karena tindakan korupsi pemimpinnya, pembangunan yang seharusnya terjadi di Libya pun tidak dapat terwujudkan. Kepemimpinan Moammar Qaddafi yang otoriter menciptakan krisis kepercayaan bagi rakyat Libya. Sejak Moammar Qaddafi berkuasa hingga digulingkan tahun 2011 lalu, tidak ada pemilihan umum untuk memilih pemimpin Libya, karena politik Libya identik dengan cara bagaimana Moammar Qaddafi memimpin negara ini.

Hal tersebut bisa dilakukan hingga lebih dari empat dekade berkuasa hingga mengalami krisis politik tahun 2011 lalu. Revolusi di Libya berlangsung relatif lama dibanding negara yang lain. Masyarakat Libya lebih banyak dipersatukan dalam asosiasi kabilah atau tribalism sedangkan Mesir civil society lebih kuat, berbasis pada kepemimpinan ulama dan kaum cendekiawan (Apriadi Tamburaka, 2011: 251). Kondisi Libya merupakan kajian yang sangat penting bagi perkembangan regional maupun global. Barat sangat berkepentingan, siapa yang akan menjadi penguasa ladang minyak Libya yang menghasilkan lebih dari 1,6 juta barrel per hari.

Walaupun, Moammar Qaddafi telah dijatuhkan, akan tetapi Libya tidak serta merta bisa dikatakan selamat dari "masa gelap". Komposisi negara ini yang begitu beragam dari aspek demografis, belum lagi upaya penyatuan kepentingan setelah kolaborasi 
antara berbagai pihak dalam menjatuhkan Moammar Qaddafi, merupakan poin analisa penting. Bagaimanapun, masa depan Libya dalam artian bentuk negara ini dalam berbagai aspek, selanjutnya akan sangat mempengaruhi posisinya di percaturan politik internasional.

\section{METODE}

Metode yang digunakan dalam penelitian secara sistematis dan kritis. Menggunakan empat langkah yaitu heuristik, kritik sumber yang dibedakan menjadi dua kritik intern dan ekstern, interpretasi dan penulisan (Nugroho Notosusanto, 1994: 17). Pada tahap menyimpulkan sintesa dari fakta-fakta yang menjadi satu kesatuan dalam bentuk suatu karya sejarah terhadap Latar Belakang dan Masa Depan Libya Pasca Arab Spring menggunakan pendekatan sosiologis, budaya, psikologis, dan politik.

\section{HASIL DAN PEMBAHASAN}

\section{Faktor-faktor Penyebab Arab Spring di Libya.}

Berdasar pada penelitian ini dapat diketahui bahwa terjadinya Arab Spring di Libya tahun 2011 disebabkan beberapa aspek.

\section{Bidang Politik}

Dimulai dari faktor kepemimpinan dan posisi yang paling rasional sebagai "stakeholder" pemerintah, sekaligus pembuat kebijakan tertinggi di Libya, yaitu presiden. Dalam sepanjang sejarah pemerintahan Libya sistem perimbangan kekuasaan di negara ini di dominasi oleh bidang eksekutif saja, sedangkan lembaga legislatif dan yudikatif tidak lepas dari pengaruh eksekutif (presiden). Dalam sepanjang pemerintahan Libya rezim Moammar Qaddafi begitu mendominasi pemerintah. Libya menjadi negara yang sangat kaku.

Undang-undang No. 71 tahun 1972 memuat adanya larangan untuk menghina konstitusi negara. Tanpa ada penjelasan yang detail mengenai bentuk penghinaan tersebut. Hal ini jika dianalisa lebih lanjut, bisa menjadi dasar bagi negara untuk melarang semua bentuk demonstrasi terhadap pemerintah, ataupun sistem yang digunakan oleh negara. Membendung semua aspirasi rakyat, yang seyogyanya menjadi nafas dari demokrasi, dan pemerintahan "jamahiriya", yaitu suatu bentuk pemerintahan yang menghendaki posisi rakyat sebagai pemegang kekuatan terbesar (Apriadi Tamburaka, 2011: 219).

Pada April 1973, pada salah satu poin dalam revolusi kebudayaan yang dilakukan oleh Moammar Qaddafi, ia menetapkan pelarangan atas komunisme, konservatisme, kapitalisme, atheis, dan kelompok persaudaraan muslim (Agung D.H., 2011: 25). Moammar Qaddafi telah melakukan pelanggaran sangat mendasar jika ditinjau dari poin-poin hak asasi manusia yang harus dihargai secara universal, yaitu kebebasan menentukan keyakinannya dan aktivitas pribadinya. Moammar Qaddafi juga mengambil legitimasi dari Islam sebagai satu-satunya agama negara, dengan menganggap bahwa kebijakannya berlandaskan pada prinsip-prinsip Islam yang tertuang dalam Al-Qur'an yaitu Surah ke 42, ayat 38.

Penghapusan partai politik di Libya berlangsung sangat ekstrim. Moammar Qaddafi, pada Oktober tahun 1969, memberikan pidato kenegaraan yang menyebutkan bahwa Libya harus berada pada kondisi "satu", sehingga keberadaan partai politik, yang ia yakini hanya memecah belah negara dalam berbagai lingkaran-lingkaran kepentingan, dan intrik untuk mencapainya, dihapuskan. Bahkan, Moammar Qaddafi mencanangkan, bahwa semua orang yang terlibat dalam partai politik, merupakan sebuah bentuk pengkhianatan terhadap negara.

Hal ini tidak saja berkisar hanya dalam pidato Moammar Qaddafi, tetapi juga dituangkan dalam undang-undang No. 71 tahun 1972, disebutkan bahwa partai politik merupakan tindakan kriminal dan merupakan bentuk kegiatan yang membahayakan negara. Bukan hanya itu, bahkan Moammar Qaddafi menjadikan Libya sebagai negara yang sangat membatasi aktivitas politik masyarakatnya, selain dalam partai politik, bahkan jika seseorang ingin bergabung dalam komunitas internasional, apapun itu, harus melalui persetujuan negara. Jika hal tersebut 
dilanggar, akan berakibat fatal, dengan diindikasikan sebagai ancaman langsung terhadap negara. Moammar Qaddafi juga melakukan manipulasi pada pemilu-pemilu untuk melanggengkan 'status quonya'. Keberadaan masyarakat Libya dan elemen-elemen pendukungnya yang sebenarnya dapat menjadi kontrol pemerintah mengalami kebuntuan fungsi karena sistem pemerintahan yang dijalankan secara tertutup dengan 'tangan besi' (otoriter) (Agung D.H., 2011: 61).

\section{Bidang Ekonomi}

Moammar Qaddafi menasionalisasi semua bisnis asing di Libya dalam kurun 3 tahun masa kepemimpinannya, termasuk industri berat, lahan pertanian, bank, perusahaan jasa, dan firma asuransi. Pada Desember 1971, Libya menasionalisasi perusahaan minyak British Petroleum dan memutihkan dana yang mencapai US\$ 550 juta yang tersimpan di Bank Inggris. Pada tahun 1973, pemerintah Libya mengumumkan bahwa semua perusahaan minyak yang beroperasi di Libya, akan dinasionalisasi. Hal ini menjadikan negara (Libya), mengontrol 60\% dari produksi minyak domestiknya pada tahun 1974, dan semakin berkembang setiap tahunnya, mulai dari kegiatan eksplorasi, produksi, hingga proses pendistribusiannya (Agung D.H., 2011: 28).

Tahun 1977, Moammar Qaddafi mengeluarkan undang-undang yang menempatkan semua aktivitas ekonomi di Libya, di bawah kontrol negara. Perekonomian di Libya otomatis didominasi oleh sektor publik yang merupakan milik negara, dan pemerintah merupakan penentu kebijakan sentral. Sebagaimana yang diungkapkan dalam teori ekonomi, bahwa perekonomian akan menjadi "sehat" jika segala keputusan diserahkan kepada pasar. Berbeda halnya dengan Libya, dimana semua aktivitas ekonomi berada di bawah kekuasaan pemerintah termasuk sektor privat, sehingga timbul kondisi yang bertentangan.

Libyan Petroleum Company (LIPECTO) yang merupakan perusahaan minyak yang digantikan oleh The National Oil Company (NOC) pada tahun 1973, yang sekaligus men- jadi satu-satunya perusahaan yang mengelola kekayaan minyak Libya di bawah kebijakan Ministry of Petroleum yang belakangan dihapuskan dalam struktur eksekutif Libya pada tahun 1986. Bukan hanya di sektor pengelolaan minyak, negara bahkan menjadi pengelola utama di bidang-bidang lainnya, seperti air, listrik, komunikasi, transportasi, pelabuhan, bandara, listrik, jasa penerbangan, dan ekspor-impor, tanpa adanya keterlibatan pihak swasta (sebagai contoh BUMN di Indonesia, yang melibatkan pihak swasta dalam kepemilikan sahamnya).

Moammar Qaddafi menerapkan kebijakan ekonomi yang sangat radikal. Pada tahun 1978, ia mencabut undang-undang tentang sektor swasta, terutama sektor perumahan. Sikap Moammar Qaddafi yang menerapkan sistem ekonomi terpusat bukanlah hal yang baru jika melihat kecenderungan pemikirannya yang beraliran sosialis. Moammar Qaddafi sangat mempromosikan pentingnya kesetaraan dalam negara, terutama dalam hal ekonomi, sebagaimana lazimnya pandangan sosialis.

Berawal dari situ pula Moammar Qaddafi tidak membiarkan sektor swasta tumbuh, karena sebagai seorang sosialis fanatik, ia tidak mempercayai sistem ekonomi liberal yang kapitalis, yang tentu saja ditandai dengan pemberian kesempatan seluas-luasnya bagi pihak swasta dan pasar untuk menentukan hasil kompetensi ekonomi. Pandangan yang menempatkan pemerintah hanya sebagai pengawas, dan bukan pengontrol langsung. Moammar Qaddafi tidak menyepakati hal ini bisa membawa kesejahteraan dan equity bagi masyarakat. Meskipun pada faktanya, sistem ekonomi yang ia terapkan berupa "true economic independence" dengan menasionalisasi semua aset dan menolak investasi asing, juga gagal membawa kesejahteraan yang diinginkan.

Libya memiliki kekayaan alam yang sangat banyak, baik dalam terminologi kekayaan alam yang masih terpendam ataupun yang telah di eksploitasi dengan angka penghasilan yang fantastis. Al Jazeera menuliskan dalam salah satu artikelnya, "Background on the politics, economy and foreign relations of 
Libya", bahwa dengan GDP sebesar 74,23 Milliar USD, dan pendapatan per kapita mencapai US\$ 13.800 pada tahun 2010, Libya seharusnya mampu menyediakan kesejahteraan bagi masyarakatnya (www.aljazeera.com. 19/04/2011).

Faktanya, tingkat pengangguran dan kemiskinan masih tinggi di Libya. Meskipun AlJazeera juga mengakui tidak adanya indeks statistik resmi tentang hal tersebut, akan tetapi banyak analis yang menuliskan angka pengangguran 30 persen atau sepertiga di Libya, dan sebagian besar pengangguran ini adalah angkatan muda Libya. Ternyata Libya lebih memilih menggunakan jasa pekerja asing dengan tingkat pendidikan yang lebih baik untuk bekerja di bidang pengolahan minyak, konstruksi, dan medis.

Aspek lain yang bisa dianalisa dari isu sistem ekonomi terpusat yang menyebabkan kesenjangan di Libya terdapat pada kekayaan putra-putra Moammar Qaddafi. Pasca revolusi, dalam sebuah aksi penggeledahan oleh NTC ditemukan sejumlah besar uang dan emas ditemukan di Tripoli, di kantor milik dari Saif al- Islam Khadafi yang merupakan putra kedua Moammar Qaddafi.

Al-Jazeera menuliskan bahwa korupsi yang dilakukan oleh keluarga Moammar Qaddafi-lah yang merupakan faktor penghalang pembangunan ekonomi di Libya (secara pertumbuhan ekonomi dengan melihat GDP, Libya termasuk positif, tetapi tidak terdapat pemerataan/pembangunan ekonomi yang merata). Moammar Qaddafi diindikasikan menggelapkan uang Negara senilai puluhan milyar USD, menyelundupkannya dalam berbagai akun bank di luar negeri. Korupsi ini bahkan disebutkan tidak hanya terjadi dalam lingkupan keluarga Moammar Qaddafi, termasuk para kolega dekatnya atau para member elite, menjadi kalangan yang memperkaya diri sendiri (www.aljazeera. com. 19/04/2011).

Pada tahun 2011 kondisi sosial-politik Libya mengalami destabilisasi yang berujung pada terjadinya krisis yang dikenal dengan perang sipil Libya tahun 2011. Kasus ini menimbulkan kerugian perekonomian serius bagi Libya, selain itu, krisis Libya tahun 2011 juga menyebabkan korban jiwa, baik dari pihak pemerintah ataupun kelompok demonstran anti pemerintah yang kemudian berujung pada jatuhnya rezim Moammar Qaddafi.

\section{Bidang Kebijakan Luar Negeri}

Di awal menduduki tampuk pemerintahan Libya, Moammar Qaddafi mengusung satu visi bagi Libya untuk menjadi pemrakarsa bersatunya Negara-negara Arab (Arab unity) (Agung D.H., 2011: 28). Dalam pemikiran Moammar Qaddafi, persatuan negara-negara Arab yang membentang dari Teluk Persia hingga ke Samudera Atlantik, akan menjadi sebuah blok kekuatan yang sangat lengkap, kepemilikan akan sumber daya mineral (terutama pasokan minyak), serta kekuatan sumberdaya manusia, dan tentu saja wilayah yang sangat luas.

Moammar Qaddafi merasa tersentak melihat begitu besar dan kuatnya federasi yang dibangun oleh Amerika Serikat dan Uni Soviet, meskipun di tubuh kedua negara besar ini terdapat banyak sekali keberagaman. Berbeda halnya dengan negara-negara Arab, yang memiliki ciri fisik yang sama, bahasa sama, dan terutama keterikatan sejarah yang sama. Ia melihat hal ini, seyogyanya dijadikan dasar yang kuat untuk menjadi blok kekuatan dunia.

Rencana besar Moammar Qaddafi untuk persatuan Arab dan menjadi major actor di Afrika, pada kenyataannya tidak berjalan dengan baik, apalagi dengan kematian Gamal Abdul Nasser di tahun 1970 (Agung D.H., 2011: 29). Faktor lain yang menyebabkan gagalnya impian Moammar Qaddafi untuk Arab Unity adalah figurnya sebagai tokoh muda. Saat itu negara-negara Arab tidak merasa yakin untuk menempatkan kepentingannya terhadap seorang pemimpin muda dan masih dianggap naiff. Selain itu, Moammar Qaddafi pada dasarnya melanjutkan ide dari idolanya, Gamal Abdul Nasser yang belum terwujud.

Sedangkan dalam perspektif para pemimpin Arab yang pragmatis, sangat sulit untuk mengikuti sebuah visi yang begitu lama belum mampu terwujud, apalagi kemudian rencana besar Moammar Qaddafi ini, diikuti oleh serentetan kegagalan membina hubu- 
ngan dengan rekan-rekan Arabnya. Hubungan Libya yang buruk dengan Negara Barat, dimulai oleh Presiden Ronal Reagan hingga Presiden Barack Obama (Presiden Amerika saat terjadinya revolusi menumbangkan Moammar Qaddafi). Presiden Reagan memasukkan Libya dalam daftar negara yang mendukung terorisme internasional (www. aljazeera.com.19/04/2011).

Dari segi kebijakan politik luar negeri, Moammar Qaddafi yang pernah menempatkan Libya sebagai negara Pariah, menempuh kebijakan sebagai negara tertutup, Hal ini memberikan kejenuhan kepada masyarakat Libya. Moammar Qaddafi yang begitu keras dalam hal manuver politiknya di tingkatan domestik, dalam bidang ekonomi juga ia menerapkan sistem menolak berbagai bentuk investasi asing, sehingga timbul berbagai tekanan baik secara sosial maupun ekonomi terhadap rakyat Libya.

Hal ini diperparah dengan kebijakan luar negeri Moammar Qaddafi yang radikal memberikan pula berbagai sanksi yang mempengaruhi keberlangsungan negara ini dan tentu saja citra Libya menjadi sangat jelek. Ditilik dari konsep People Power sendiri kondisi inilah yang menuntun rakyat Libya untuk bergerak mengganti kondisi yang disediakan pemerintahan Moammar Qaddafi. Harapan rakyat setelah berbagai tragedi yang menimpa Libya termasuk pemboman oleh Amerika Serikat ke Tripoli, tidak ditanggapi baik oleh Moammar Qaddafi. Bahkan ia masih sibuk untuk mewujudkan ambisi pribadinya. Di sinilah kemudian rakyat Libya menjadi sangat jenuh dan memobilisasi dirinya dengan pihak oposisi guna mengganti sistem yang ada.

\section{Masa Depan Libya Pasca Arab Spring}

a. Demokratisasi Bidang Politik dan Pemerintahan

Perang sipil Libya yang berlangsung antara bulan Februari hingga Oktober 2011 mengakibatkan ribuan orang tewas. Jumlah pasti korban tewas tidak diketahui, namun diperkirakan jumlahnya berkisar antara 10.000 hingga 40.000 jiwa di mana mayoritasnya merupakan warga sipil. Akibat perang itu pula, timbul arus pengungsi keluar Libya yang jumlahnya mencapai ratusan ribu orang di mana kebanyakan dari mereka mengungsi ke negara-negara sekitar Libya seperti Mesir \& Tunisia. Tidak diketahui berapa kerugian material akibat perang tersebut, namun nilai kerugiannya pasti sangatlah besar kalau melihat intensitas perang sipil yang membakar Libya.

Sejak perang sipil berakhir, pihak National Transitional Council (NTC) selaku pemenang perang langsung melakukan sejumlah perubahan. Bendera Libya yang awalnya berawrna hijau polos diganti dengan bendera bermotif tiga warna \& bulan sabit. Sistem pemerintahan "jamahiriya Arab" buatan almarhum Moammar Qaddafi yang berhaluan sosialis juga dihapuskan \& diganti menjadi sistem republik. Sepeninggal Moammar Qaddafi, Libya berada dalam kondisi euforia atas kebebasan, setelah puluhan tahun berada dalam rezim yang represif. Akan tetapi, Libya sebagai sebuah negara menjadi sangat rentan. Ada banyak syarat yang harus dipenuhi secepatnya untuk menjaga keberlangsungan Libya sebagai sebuah negara, yaitu konstitusi negara, ideologi negara, pembentukan pemerintahan yang baru melalui pemilihan umum, perbaikan infrastruktur, political maping terhadap dunia internasional, dan sebagainya.

Berdasarkan visi Libya yang tertuang dalam "A Vision of A Democratic Libya" ada beberapa indikator dalam bidang politik dan pemerintahan yang harus dipenuhi oleh NTC untuk mencapai kestabilan Libya, yaitu:

Pemilihan umum dengan respon positif pada tahun 2012. Libya harus segera memiliki kejelasan struktur pemerintahan untuk mendapatkan legitimasi dalam setiap kebijakan yang dikeluarkan.

Disarmament terhadap para milisi. Sebelum pemilu dilaksanakan, pihak NTC harus sudah memberikan konsensus politik yang sesuai terhadap para milisi untuk menyerahkan senjatanya dan mempercayakan tugas mengamankan Libya pada otoritas yang ada.

Pembentukan konstitusi negara yang baru. Konstitusi negara merupakan dasar politik negara. 
Konsolidasi ideologi negara yang baru. Untuk memiliki political will yang sama, negara harus memiliki ideologi yang diterima oleh masyarakatnya.

Terjaminnya kebebasan individu dalam berpendapat. People Power yang terjadi di Libya, salah satu penyebabnya adalah hasil ketidakpuasan masyarakat Libya selama 42 tahun, yang terpendam, berbagai aspirasi ketidaksetujuan masyarakat terhadap kebijakan Moammar Qaddafi, akan tetapi tidak bisa dilampiaskan.

Sistem check and balance yang efektif. Selama ini di Libya tidak terdapat sistem check and balance yang efektif dikarenakan sistem jamahiiya yang digunakan, menjadikan Moammar Qaddafi penguasa yang sangat dominan di Libya, serta dukungan rezimnya juga menyebabkan tidak adanya kontrol agar kekuasaan pemimpin negara tidak berlebihan.

Struktur pemerintahan yang sesuai dengan karakter bangsa dengan pertimbangan Libya merupakan negara yang sangat heterogen sehingga konsep demokrasi dan bentuk struktur pemerintahan yang selama ini dikenal tidak bisa serta merta diterapkan di Libya.

Pemerintahan yang kuat. Keberadaan Amerika Serikat dan NATO dalam upaya menjatuhkan Moammar Qaddafi tidak bisa dipandang secara naif hanya sebagai sebuah bantuan kemanusiaan untuk membebaskan sebuah negara dari rezim otoriter. Terdapat kepentingan di dalamnya dan kepentingan tersebut cepat atau lambat akan menjadi hal yang mempengaruhi kebijakan yang diambil oleh pemerintah Libya yang baru.

Mobilisasi rakyat Libya (State consolidation). Libya merupakan negara yang sangat beragam dari segi suku, dan keberagaman ini merupakan identitas yang berusaha dihapuskan oleh Moammar Qaddafi menjadi "hanya Libya" pada masa pemerintahannya. Setelah berhasil menjatuhkan Moammar Qaddafi pemerintahan yang baru harus bisa memfasilitasi semua pihak di Libya agar memiliki hak yang sama dalam berbagai bidang.

\section{b. Demokratisasi Bidang Ekonomi}

Di bidang ekonomi, perusahaan minyak nasional Libya mulai beroperasi kembali sejak bulan Januari 2012. Namun, kegiatan pengilangan sendiri belum bisa berjalan secara maksimal karena masih banyaknya fasilitas perminyakan yang rusak akibat perang. Patut diketahui masalah ekonomi merupakan salah satu pekerjaan rumah terbesar bagi pemerintahan Libya yang baru. Libya memiliki sumber daya yang sangat besar, terutama sumber daya mineral.

Hal ini bukan hanya sangat penting pengelolaannya bagi kondisi domestik negara, akan tetapi kebijakan bidang ekonomi Libya akan menentukan hubungan Libya dengan negara-negara lain, terutama Negara Barat. Banyak pihak yang menganalisa keberadaan NATO dan AS dalam upaya menjatuhkan rezim otoriter Moammar Qaddafi, bukan hanya karena adanya good will untuk membebaskan Libya dari pemerintahan yang buruk, akan tetapi juga karena ada kepentingan terhadap sumber daya minyak Libya.

Ada beberapa indikator dalam bidang ekonomi yang harus dipenuhi oleh NTC untuk mencapai demokratisasi bidang ekonomi di Libya, yaitu:

1. Kebijakan pengelolaan sumber daya alam khususnya mineral yang tepat. Pembangunan ekonomi yang dilakukan harus menyentuh semua lapisan.

2. Perbaikan infrastruktur dan layanan sosial serta pembayaran gaji pegawai.

3. Kebijakan ekonomi terutama dalam hal penerimaan investasi asing sebab selama ini Libya dikenal menolak segala bentuk kehadiran pihak asing di negaranya salah satunya dalam hal investasi.

\section{Pencairan aset di luar negeri.}

Kebijakan ekonomi Libya harus tepat, sebab begitu Libya memutuskan untuk menjadi negara demokrasi, atau apapun bentuk pemerintahannya nantinya, Libya akan menjadi area tawar-menawar berbagai negara yang membutuhkan sumber daya mineralnya. Jika Libya tidak mampu membaca peta situasi dan mengambil kebijakan ekonomi yang salah, Libya akan terjebak pada kenyataan yang sama dengan Irak. Dalam hal 
ini "desired future" atau masa depan yang ditakdirkan untuk Libya tidak akan jauh berbeda dengan Irak.

Otoritas baru Libya juga perlu untuk mempertimbangkan bagaimana pengelolaan sumberdaya mineral ini dalam hal pemerataan pembangunan ekonomi. Demokratisasi bidang ekonomi Libya memiliki kecenderungan akan berujung pada sistem ekonomi liberal, sebagaimana yang dianut oleh Amerika Serikat dan sebagian besar negara demokrasi.

\section{Perubahan Arah Kebijakan Luar Negeri}

Revolusi yang terjadi akibat People Power untuk menjatuhkan Moammar Qaddafi menunjukkan adanya ketidaksepahaman rakyat Libya dengan pemikiran Moammar Qaddafi, termasuk dalam hal kebijakan luar negeri. Tindakan Moammar Qaddafi dengan visi Arab Unity dan kemudian African Unity-nya, telah memberikan dampak sanksi yang begitu memukul rakyat Libya. Sehingga setelah Moammar Qaddafi tiada dan kemudian terjadi perganian otoritas di Libya, bisa dipastikan akan terjadi perubahan arah kebijakan luar negeri di Libya.

Ada beberapa hal yang harus dicapai oleh pemerintahan baru Libya dalam kebijakan politik luar negerinya, yaitu: mendapatkan pengakuan dari negara lain. Sudah lumrah diketahui dalam studi ilmu hubungan internasional, bahwa salah satu syarat berdirinya suatu negara adalah adanya pengakuan dari negara lain. Pihak oposisi yang telah menggulingkan pemerintahan yang lama, membutuhkan pengakuan dari dunia internasional, untuk mendapatkan legitimasi dalam setiap kebijakan politik luar negerinya, sebagai pemerintahan yang sah atas Libya.

Selanjutnya, pemerintah Libya perlu melakukan maintain control terhadap perbatasan untuk menjaga kedaulatan negara disaat kondisi internal sedang tidak kondusif. Perbaikan hubungan dengan negara-negara kontra-Moammar Qaddafi merupakan agenda penting pula dalam kebijakan politik luar negeri Libya kedepannya. Perubahan dari pemerintahan Moammar Qaddafi yang antiBarat, ke pemerintahan baru yang "welcome" terhadap Pemerintahan Barat.
Niat untuk membina hubungan baik dengan pemerintahan Barat, sebenarnya bisa dibaca sejak awal People Power terjadi. Meskipun gerakan ini murni merupakan solidaritas di kalangan rakyat Libya, akan tetapi pada perjalanannya saat Moammar Qaddafi berusaha memadamkan para pemberontak, rakyat Libya yang termasuk dalam gerakan ini bersama pihak oposisi mendapatkan bantuan dari Amerika Serikat dan NATO, yang seyogyanya merupakan musuh bebuyutan Moammar Qaddafi, dan sudah merupakan suatu kelumrahan jika Amerika Serikat dan NATO menyambut baik niat rakyat Libya untuk membebaskan negaranya dari rezim otoriter.

Analisa di atas menunjukkan bahwa Libya di masa depan akan menjadi area pertarungan kepentingan banyak negara. " $\mathrm{Vi}$ sion of Democratic Libya" yang dikeluarkan oleh NTC, mengindikasikan perubahan arah kebijakan luar negeri dari hard profile yang ambisius di masa Moammar Qaddafi, ke low profile atau lebih moderat, dan menunjukkan niat negara yang patuh terhadap hukum internasional. Hal ini juga menegaskan bahwa di masa depan, Libya akan menjadi negara yang menghindari konfrontasi dalam penyelesaian konflik dengan negara lain. Hal yang sangat berbeda dari Moammar Qaddafi.

Perubahan ke arah yang lebih soft tersebut, bukanlah sebuah pilihan yang buruk. Selain untuk membangun Libya yang baru, dimana memang dibutuhkan banyak dukungan internasional, sehingga Libya mau tak mau harus memperbaiki citranya. Juga untuk memenuhi harapan rakyat Libya yang menginginkan perubahan dari pemerintahan sebelumnya. Akan tetapi, bagian terberat dari perubahan tersebut adalah menjaga posisi Libya dalam kancah perpolitikan di dunia internasional, khususnya di Afrika, sebagai negara yang disegani, bahkan menjadi leader di regional Afrika.

\section{PENUTUP}

Melalui uraian pembahasan di atas maka dapat disimpulkan bahwa krisis Libya tahun 2011 atau yang dikenal dengan perang 
sipil Libya tahun 2011 merupakan salah satu revolusi sosial-politik yang terjadi di Jazirah Arab bersama-sama dengan Tunisia dan Mesir. Kasus ini bukan terjadi secara euforia, yaitu adanya dependensi antara negara dengan negara lain pada satu kawasan yang sama, namun dilatarbelakangi oleh berbagai problematika yang kompleks.

Berakhirnya rezim Moammar Qaddafi yang otoriter merupakan awal mula proses demokratisasi itu sendiri. Korban manusia, harta benda ataupun kehancuran kota-kota di Libya menjadi awal mula terciptanya demokratisasi di Libya, dan juga di Timur Tengah karena Tunisia dan Mesir yang sudah lebih dulu tercipta demokratisasi di dalamnya menjadi pendorong bagi negara-negara Arab lainnya untuk menciptakan demokratisasi yang menjunjung tinggi kepentingan rakyat.

Keberhasilan menjatuhkan rezim Moammar Qaddafi melalui People Power, kini pemerintah Libya yang baru telah menyusun suatu sistem ketatanegaraan yang baru bagi Libya, dengan mengadopsi segala aspirasi dan kepentingan rakyatnya. NTC membuat visi Libya ke depannya sebagai negara demokrasi dengan paduan syariah Islam, menekankan pada poin political democracy and value of social justice. Dalam bidang politik dan pemerintahan, NTC sebagai otoritas baru Libya masih gagal memimpin Libya sejauh ini. Dimana konsolidasi nasional yang dilakukan belum berhasil. Masih banyak milisi lepas yang berkeliaran dan menimbulkan insecurity di Libya dan semakin maraknya perkelahian antar-suku. Selain itu, belum adanya figur yang tepat untuk menggantikan Moammar Qaddafi, juga mempengaruhi hal tersebut.
Bidang ekonomi, Libya cenderung akan mengadopsi sistem ekonomi Liberal. Perbaikan infrastruktur, layanan sosial, serta pencairan aset di luar negeri menjadi agenda yang ingin dicapai oleh pemerintah Libya yang baru. Apalagi di tengah kondisi banyaknya negara besar yang berminat terhadap sumber daya mineral Libya. Kebijakan luar negeri Libya ke depannya akan cenderung ke arah low profile dengan menghindari konfrontasi atau lebih moderat. Mengutamakan pembinaan hubungan baik dengan negara lain, terutama negara tetangga yaitu sesama Negara Arab dan Negara Afrika.

\section{UCAPAN TERIMA KASIH}

Terima kasih kepada semua pihak yang membantu penulisan artikel ini serta kepada redaktur jurnal yang memuat artikel ini. Semoga artikel ini bermanfaat.

\section{DAFTAR PUSTAKA}

D.H., Agung. 2011. Khadafi (Anjing Gila dari Sahara). Yogyakarta: Narasi.

Notosusanto, Nugroho. 1994. NormaNorma dan Penulisan Sejarah. Jakarta: Departemen Pertahanan dan Keamanan.

Nn. 2011. "Country Profile : Libya. Background on the politics, economy and foreign relations of Libya." http:// www.aljazeera.com/news/middleeast/ 2011/04/201141912643168741.html. diunduh pada 25 Juli 2011.

Tamburaka, Apriadi. 2011. Revolusi Timur Tengah (Kejatuhan Para Penguasa Otoriter di Negara-negara Timur Tengah). Yogyakarta: Narasi. 